\title{
Online Dispute Resolution: Some Implications for the Emergence of Law in Cyberspace
}

\author{
Ethan KATSH* \\ Lex Electronica, vol.10 n³, Hiver/Winter 2006 \\ http://www.lex-electronica.org/articles/v10-3/katsh.htm
}

"What, then, is this law business about? It is about the fact that our society is honeycombed with disputes. Disputes actual and potential, disputes to be settled and disputes to be prevented; both appealing to law, both making up the business of law.This doing something about disputes, this doing of it reasonably, is the business of law."

-Karl Llewellyn ${ }^{1}$

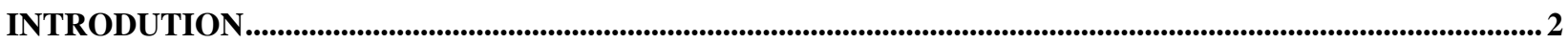

1. THE GROWTH AND EVOLUTION OF ONLINE DISPUTE RESOLUTION .................................................. 3

2. SOME LESSONS FROM THE PAST DECADE ..........................................................................................6

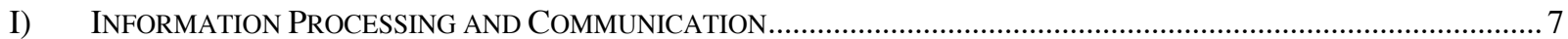

II) RULE FORMATION AND THE COMMUNICATION AND PROCESSING OF INFORMATION ..................................... 9

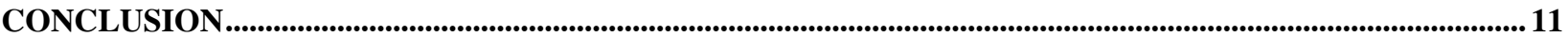

Professor of Legal Studies and Director, Center for Information Technology and Dispute Resolution, University of Massachusetts at Amherst, email: Katsh@legal.umass.edu Web: http://www.odr.info This article is a product of research supported by National Science Foundation award \# 0429297 "Process Technology for Achieving Government Online Dispute Resolution." < http://www.fastlane.nsf.gov/servlet/showaward?award=0429297>

1 Llewellyn, Karl, The Bramble Bush (Dobbs Ferry, N.Y.: Oceana Publications, 1960), p. 2. 


\section{Introdution}

The tenth anniversary of Lex Electronica largely coincides with the tenth anniversary of two other significant cyberlaw events. The first, the May, 1996 conference on online dispute resolution sponsored by the National Center for Automated Information Research can be viewed as the beginning of the online dispute resolution movement. This is a movement that has grown from a single dispute handled by an entity called the Virtual Magistrate to several million disputes handled by an Internet start-up SquareTrade. The second, also occurring in May, 1996, was the publication in the Stanford Law Review of David Johnson's and David Post's seminal article "Law and Borders - The Rise of Law in Cyberspace."2

The Johnson and Post article launched a rather heated and still ongoing debate. At the risk of oversimplification, one side in this debate holds that authoritative rules for cyberspace can and should come from territorial states. ${ }^{3}$ The other, articulated by Johnson and Post in their article, argues that there are sufficient reasons for considering cyberspace to be a separate place which can and should make its own rules. At a more basic level, the question being asked is what impact the new technologies are having on the authority and power of states to make and enforce law. And at perhaps an even more basic level, the focus is on issues such as what law is and how it emerges and evolves, issues that have a long history and, still, uncertain answers.

Given how many disputes are generated by online transactions, interactions and relationships, the development of processes for using the Web for to respond to such problems is deserving of significant attention in its own right. Yet, dispute resolution, an acknowledged core responsibility of law, may, as will be explained below, acquire new responsibilities and characteristics as it develops online. During the period when scholars have been debating whether states will cede any of their sovereign authority to some kind of entity in cyberspace, states have, with relatively little notice, been more than willing to allow dispute resolution processes to migrate to cyberspace. This has occurred not only with no resistance but with some encouragement. It has also been occurring with little understanding that processes that migrate to cyberspace often change as they take advantage of capabilities for communicating and processing information that are not available or employed offline. When this occurs, unintended consequences, for example changes in how and where rules originate, may also occur.

Consider, for example, a practice that involves some regulation of the flow of information, such as whether a process is public or private. In the offline world, such a decision is embedded in the line separating litigation and what have come to be called "alternative dispute resolution processes." Litigation is a public process both in the sense that it is open to the public and sponsored by a public authority. At the risk of some confusion, one could also say that it is public (open) because it is public (sponsored by government). As processes of negotiation, mediation and arbitration are employed online, and as the context in which these processes are employed changes, the logic for guaranteeing confidentiality may be less compelling. Such a shift not only affects the process for settling disputes but, if results are public and published, can lead to new ways of standard setting. Were this to occur, it would have implications for the core question in the Johnson and Post debate, namely how effective rules for cyberspace will emerge.

2 David R. Johnson and David Post, "Law And Borders - The Rise of Law in Cyberspace," 48 Stan. L. Rev. 1367 (1996).

3 Jack L. Goldsmith, “Against Cyberanarchy,” 65 U. Chi. L. Rev. 1199 (1998).

Ethan KATSH, "Online Dispute Resolution: Some Implications for the Emergence of Law in Cyberspace”, Lex 


\section{The Growth and Evolution of Online Dispute Resolution}

While the Internet began in 1969, a need for ODR did not emerge until the early 1990s. For its first two decades, the Internet was used by a limited number of people in a limited number of ways. Those with Internet access were associated either with the military or with academic institutions, and even in those environments, relatively few computers had Internet access. While screens with images and email with advertisements are commonplace today, they were unknown at that time. The World Wide Web was not invented until 1989 and, perhaps even more significantly, the National Science Foundation banned commercial activity from the Internet until $1992 .{ }^{4}$

In the early 1990s, groups used "listservs" to communicate, and this form of online discussion soon generated "flaming" and violations of "netiquette," personal attacks that violated generally accepted norms for online discussions. ${ }^{5}$ Disputes also arose involving participants in role playing games that allowed one to create an online identity and interact with others in a virtual "space." Various online mechanisms were employed to deal with these conflicts, but there were no organized dispute resolution institutions devoted specifically to ODR. Indeed, the acronym ODR had not yet been invented.

The decision by the National Science Foundation in 1992 to lift its ban on Internet-based commercial activity was highly controversial and enormously significant. After the ban's removal, disputes related to online commerce began to surface. In 1994, for example, the first commercial spam occurred when two lawyers tried to recruit clients to participate in an immigration scam. ${ }^{7}$ A few months later, the U.S. Federal Trade Commission filed its first case alleging online fraud. ${ }^{8}$ The case involved an AmericaOnline subscriber who advertised the following:

\section{FOR JUST \$99.00 WE WILL SHOW YOU HOW TO CREATE A BRAND NEW CREDIT FILE AT ALL 3 OF THE MAJOR CREDIT BUREAUS...100\% LEGAL AND 200\% GUARANTEED.}

The FTC did not consider the process to be legal or guaranteed. As a result of the FTC action, the subscriber agreed to stop advertising credit repair programs and to provide compensation to consumers.

The need for a sustained ODR effort to respond to growing number of disputes arising out of online activities prompted the National Center for Automated Information Research (NCAIR) to sponsored a conference on online dispute resolution in $1996 .{ }^{9}$ The conference was the most significant development during the mid-1990s, as it led to the funding of three experimental ODR projects. The Virtual Magistrate project aimed at resolving disputes between Internet Service

\footnotetext{
4 Jay P. Kesan, and Rajiv C. Shah. Fool Us Once Shame On You - Fool Us Twice Shame On Us: What We Can Learn From the Privatizations of the Internet Backbone Network and the Domain Name System. $<$ http://papers.ssrn.com/sol3/papers.cfm?abstract id=260834>

$5 \quad$ Virginia Shea. Netiquette. 1997. <http://www.albion.com/netiquette/book/0963702513p3.html>

6 Julian Dibble. 1993. A Rape in Cyberspace. The Village Voice $<\mathrm{http}: / / \mathrm{www} . j u l i a n d i b b e l l . c o m / t e x t s /$ bungle.html>

7 Ray Everett-Church, "The Spam That Started It All," <http://www.wired.com/news/politics/0,1283,19098,00.html>

$8 \quad$ http://www.ftc.gov/opa/1999/9912/case121599.pdf

9 Papers from the conference are accessible at http://www.odr.info/ncair
}

Ethan KATSH, "Online Dispute Resolution: Some Implications for the Emergence of Law in Cyberspace", Lex 
Providers and users. ${ }^{10}$ The University of Massachusetts Online Ombuds Office hoped to facilitate dispute resolution on the Internet generally. ${ }^{11}$ Finally, the University of Maryland proposed to see if ODR could be employed in family disputes where parents were located at a distance.

These very early efforts at online dispute resolution copied the qualities and approaches of offline processes. There was novelty to these efforts in that they handled conflicts originating in cyberspace or related to cyberspace. There was also novelty in that the network was used to allow the third party to interact with the parties in lieu of face to face meetings. What one might call the paradigm of alternative dispute resolution, however, two parties negotiating or a human third party mediating or arbitrating, was largely preserved. The network allowed a third party to provide the expertise of a human to distant parties but information processing and information management capabilities of computers linked to the network were not employed.

In 1997, the Hewlett Foundation provided funding for the establishment of a Center for Information Technology and Dispute Resolution at the University of Massachusetts and in 1999, the online auction site eBay, asked the Center to conduct a pilot project to determine whether online mediation could assist in the resolution of disputes between buyers and sellers. ${ }^{12}$ eBay currently has over one hundred and sixty million registered users and over twenty five million transactions take place each week. eBay itself is not a party to any transaction and, in general, assumes no responsibility for problems that arise between buyers and sellers. While the percentage of transactions that lead to disputes is low, the number of such disputes is considerable.

The UMass pilot project handled over two hundred disputes in two weeks. As a result of the success of the project, eBay selected an Internet start-up, SquareTrade, to be its dispute resolution provider. ${ }^{13}$ SquareTrade realized that, in order to handle large numbers of cases, technology needed not only to allow parties to communicate at a distance but that it needed to assist parties in negotiating effectively and assist them in reaching consensus. Thus, SquareTrade designed a two step dispute resolution process. The first step was a Web-based technologysupported negotiation process in which parties tried to resolve the dispute themselves. If this failed, the parties could request a human mediator.

ODR has been assumed by many to be negotiation via email. Email allows easy and quick communication but email software provides limited information management resources and places most of the responsibility for organizing the information in emails on the user. SquareTrade's use of the Web illustrates how even relatively small changes in information processing can have large consequences. Parties filing claims through SquareTrade have already tried to negotiate via email and have reached impasse. Parties participating in the SquareTrade process are required to communicate through a structured Web site and through forms that frame the dispute and the negotiation of solutions. Not only do parties seem more willing to negotiate

10 Robert Gellman. “A Brief History of the Virtual Magistrate Project: The Early Months” (1996). < <http://www.odr.info/ncair/gellman.htm>

11 Ethan Katsh, "The Online Ombuds Office: Adapting Dispute Resolution to Cyberspace" (1996) < http://www.odr.info/ncair/katsh.htm>

12 Ethan Katsh. Janet Rifkin and Alan Gaitenby, "E-Commerce, E-Disputes, and E-Dispute Resolution: In the Shadow of "eBay Law," 15 Ohio St. J. on Disp. Resol. 705 (2000) <http://www.umass.edu/cyber/katsh.pdf>

$13<$ www.squaretrade.com>

Ethan KATSH, "Online Dispute Resolution: Some Implications for the Emergence of Law in Cyberspace", Lex 
via the Web than email, but the negotiations are more frequently successful. ${ }^{14}$ SquareTrade recognizes that almost all eBay disputes fall into eight to ten categories, thus allowing it to create forms that clarify and highlight both the parties' disagreements and their desired solutions. While parties have an opportunity to describe concerns in their own words, the forms and the form summaries they receive reduce the amount of free text complaining and demanding, and thus lower the amount of anger and hostility between them.

Negotiation, as classically defined, takes place between the disputants, without the presence of third parties. The use of the web in negotiations, as just described, added a novel element to traditional negotiation, a kind of "virtual presence." The Web site frames the parties" communication and provides some of the value traditionally provided by a mediator. It has been suggested that a useful way to understand the role of technology is to consider it a "fourth party." 15 The "fourth party" metaphor alludes to a use of technology that, like a mediator, can play different roles and have a different impact in different contexts. In negotiation, the "fourth party" can provide some of the value often found in mediation, by assisting the parties to identify common interests and by helping them to generate mutually acceptable solutions. In other contexts, where there is a mediator or arbitrator, the "fourth party" can alter the role(s) of a third party since the third party will increasingly be interacting with an electronic ally as well as with the disputants.

Efficient information management and organization, including effective displays of information for disputants, has allowed SquareTrade to process over two million disputes during the last five years. eBay has recently been developing software for particular kinds of disputes that it believes will be employed in twenty five million disputes in one year alone. This kind of software does not make decisions or even suggest outcomes but does control and shape the flow of information, clarify issues and present information on screen that highlights areas of agreement and difference. ${ }^{16}$ Like a mediator, the software maintains a respectful discourse between the parties until the contours of a solution acceptable to the parties appear.

The other large scale process aimed at settling disputes at a distance is focused on claims that a domain name has infringed a trademark. For the Internet to function, every computer connected to it must have a unique identifying number or Internet address. Such addresses typically look something like 128.119.28.27. Because humans find it difficult to remember strings of numbers, a system was developed that allowed a domain name, such as adr.org, to be typed in instead of the number string. What occurred when someone typed in the domain name was that a machine somewhere translated it into the number string, something the computer could process to find a particular machine.

The demand for domain names grew as commercial activity on the Internet grew and as businesses wanted potential customers to have an easy way to find them. The domain name system had been designed before commercial activity was permitted on the Internet and it had not been anticipated that many businesses with similar names might want the same domain name, or that owners of trademarks would be upset if someone registered a domain name that was similar

14 < http://www.odr.info/unece2003/pdf/Abernethy.pdf>

15 Ethan Katsh, and Janet Rifkin, 2001. Online Dispute Resolution: Resolving Conflicts in Cyberspace. San Francisco: Jossey-Bass, Inc.

16 See, for example, the capabilities of software such as SmartSettle http://www.smartsettle.com or blind bidding from Cybersettle http://www.cybersettle.com

Ethan KATSH, “Online Dispute Resolution: Some Implications for the Emergence of Law in Cyberspace”, Lex 
to a trademark. The combination of domain name scarcity and the concerns of trademark holders led to disputes over domain names.

In 1998, the United States government agreed to allow a new organization, the Internet Corporation for Assigned Names and Numbers (ICANN) to manage the domain name system. One of the first things ICANN did was enact the Uniform Dispute Resolution Policy establishing both a process and a set of rules for deciding domain name disputes. ${ }^{17}$ Both the approach ICANN chose, a modified arbitration process, and the systems which have implemented this approach, represent another choice in moving dispute resolution online. The process employed to resolve domain name disputes is interesting in a number of ways.

a. UDRP dispute resolution occurs without face to face meetings and, except in rare instances, without telephone communication. It is, therefore, dispute resolution at a distance. The process employed by the current dispute resolution providers, however, involves limited use of the Internet. One of the original dispute resolution providers, eResolution.com, did employ a completely online system but it stopped handling cases in 2001. Both current providers, the World Intellectual Property Organization (WIPO) and the National Arbitration Forum (NAF) have online systems that could be employed and probably will be employed in the future. Currently, online filings are occurring with increasing frequency and email is employed sometimes. Unlike the eBay mediations, however, the Web is not employed and if there is added value that could be provided by Web-based processes, such value is not yet present.

b. The UDRP is not classic arbitration in that the decisions are not binding and enforceable in court. ${ }^{18}$ UDRP arbitrators are referred to as panelists since the word arbitrator denotes someone who can make a decision that is enforceable in court. UDRP panelists are empowered by terms in the contract agreed to when a domain name is registered. Decisions of arbitrators are enforced by making necessary changes in the domain name registry. The UDRP created an efficient, although somewhat unorthodox process, and not without controversy. ${ }^{19}$

\section{Some Lessons From the Past Decade}

The most obvious force driving online dispute resolution during what might be called its early childhood, has been the need to respond to growing numbers of disputes arising out of online activities and involving parties who, because of distance or cost, cannot use the courts. Dispute resolution processes are generally perceived as having a single function, that of settling problems. What has come to be understood online, perhaps more than it is offline, is that dispute resolution processes have a dual role, that of settling disputes and also of building trust. Those interested in attracting users to some online activity, whether for commerce or some other purpose, have understood that users must be provided with some measure of trust and safety in addition to convenience and cost benefits. Users, in other words, need not only to be able to do something

$17 \quad<$ http://www.icann.org/udrp>

18 Elizabeth Thornburg,. "Going Private: Technology, Due Process, and Internet Dispute Resolution.” 34 U.C. Davis L. Rev. 151, 154 (2000).

19 Milton Mueller,. 2002. Ruling the Root : Internet Governance and the Taming of Cyberspace. Cambridge, MA: MIT Press; Michael Geist , "Fair.com?: An Examination of the Allegations of Systemic Unfairness in ICANN UDRP", (August 2001) at 6. http://www.udrpinfo.com/.

Ethan KATSH, "Online Dispute Resolution: Some Implications for the Emergence of Law in Cyberspace", Lex 
online but to be willing to do it online. Creative use of technology allows us to participate in many novel activities online but participation will not occur if there is some risk associated with participating. One method of reducing perceived risk, is to let potential users to know that if problems arise, there are mechanisms in place for obtaining redress.

In any environment, the need to satisfy multiple interests may lead to compromises. We are slowly getting more powerful software that will allow ODR to be employed more effectively in more complex disputes, in multi-party and multi-issue disputes, in disputes involving public policy consensus building, and in novel online contexts such as online games and virtual worlds. ${ }^{20}$ In every new context, however, some assessment will occur of whether all the goals of the institution are attainable or whether some compromise in what can be achieved is necessary. Quite frequently, this will involve a choice between efficiency in dispute resolution by keeping conflicts confidential and the need to build trust by making processes transparent.

Can the experience of online dispute resolution illuminate any of the issues raised in the "Law and Borders" debate over the future nature and role of law in cyberspace? The past ten years have been a period of experimentation with ODR. Some of these experiments have been more ambitious than others and some more successful than others. While states and scholars have been engaged in trying to figure out the limits of state legal authority in a networked world, ODR has been given free reign to build and try out systems. Since these systems are not actually free and since they may involve development of complex software, it is obvious that we are still in an early stage of development. But for those still debating the issues raised by Johnson and Post, the following might be instructive.

\section{I) Information Processing and Communication}

Both Johnson and Post and their critics assume that it is the communication of information in novel ways, in huge quantities and for varied purposes that threatens nation states. This was certainly an arguable point in 1996 when online communication was a novelty. Today, however, what is labeled a networked environment needs to be understood as an environment in which the processing of information is integrated with the communication of information at a scale far different from what it was in 1996.

The earliest forms of ODR also saw the network simply as a communications system. Thus, email seemed an appropriate tool for communication between disputants and between disputants and third parties. Communication, of course, is a prerequisite for any dispute resolution process but we have learned that it is information management and information processing that constitutes the value that technology provides to the interaction of the parties. SquareTrade receives attention for the number of disputes it has handled but it has handled this number only because it designed information management tools that could be employed by the parties themselves.

These information management and processing tools are, of course, embedded in software. The role of software has been recognized in discussions of legal doctrine by the expression "code is the law." 21 The expression embodies the idea that behavior can be constrained by code and that

\footnotetext{
20 Ethan Katsh, "Bringing Online Dispute Resolution To Virtual Worlds: Creating Processes Through Code," 49 N.Y.L. Sch. L. Rev. 271 (2004/2005)..

21 The phrase originated with William J. Mitchell, City of Bits: Space, Place, and the Infobahn (Cambridge, Mass.: MIT Press, 1995), p. 111. See also Lawrence Lessig, Code and Other Laws of Cyberspace (1999),, Ethan
} 
these constraints are an alternative to legal rules. When "code is the process," as I think it is with software-enhanced online dispute resolution, it can be an alternative to one of the familiar dispute resolution processes or it can become part of the process. As more software is developed, we will continue to learn about the varieties of interaction between code and process.

Is information processing software of some kind other than the "code is the law" concept relevant to legal rules? This is a largely unexplored question but worthy of attention. It is easy to assume simply that law has authority because it has emanated from a sovereign body but, unless sovereignty is only a function of geography, there are also informational processes that are supporting the law. If, as we have learned from ODR during the last decade, it is the combination of information processing and communication that may ultimately affect paradigms of dispute resolution processes, perhaps something similar might impact on how law acquires authority and how citizens accept and interact with legal rules.

Marc Galanter has astutely observed, that law

usually works not by exercise of force but by information transfer, by communication of what's expected, what forbidden, what allowable, what are the consequences of acting in certain ways. That is, law entails information about what the rules are, how they are applied, with what costs, consequences, etc. For example, when we speak of deterrence, we are talking about the effect of information about what the law is and how it is administered. Similarly, when we describe 'bargaining in the shadow of the law,' we refer to regulation accomplished by the flow of information rather than directly by authoritative decision. Again, 'legal socialization' is accomplished by the transmission of information. In a vast number of instances the application of law is, so to speak, self administered -people regulate their conduct (and judge the conduct of others) on the basis of their knowledge about legal standards, possibilities and constraints. ${ }^{22}$

This was very perceptive when it was written twenty years ago but now, and certainly in the future, "information transfer" will be joined by information processing. As this occurs, all of the processes listed in the above paragraph are likely to be affected and change in some way.

An essay on the potential impact of computers on law, also from ten years ago in the Stanford Law Review, suggested that four examples from the past might illuminate the technology-driven scope of change in the future. ${ }^{23}$

The first is the story of printing. In the mid-1400s, Gutenberg invented the printing press (or, to be precise, movable type). In the centuries that followed, printing helped bring about the Reformation, the Industrial Revolution, and modern liberal democracy. Gutenberg wasn't trying to change the world: He was just making a faster, cheaper way to produce a particular commodity. But, of course, the consequence wasn't simply that book buyers saved money; the technological change dramatically altered the social and political landscape. Likewise, three hundred and fifty years after Gutenberg, Eli Whitney patented the cotton gin. It

Katsh, "Software Worlds and the First Amendment: Virtual Doorkeepers in Cyberspace," University of Chicago Legal Forum (1996): 335, 338. Joel Reidenberg, "Lex Informatica: The Formulation of Information Policy Rules Through Technology," 76 Texas Law Review (1998): 553.

$22 \quad$ Marc Galanter, "The Legal Malaise: Or, Justice Observed," 19 Law and Society Review 537, 545 (1985).

$23 \quad$ Eugene Volokh, "Technology and the Future of Law," 47 Stan. L. Rev. 1375 (1995).

Ethan KATSH, "Online Dispute Resolution: Some Implications for the Emergence of Law in Cyberspace", Lex 
certainly wasn't intended to extend slavery by decades and kill hundreds of thousands people in a civil war, but it may have had a big hand in doing both.

The second is the story of the slide rule. The slide rule was a marvelously elegant mathematical device, and it earned its manufacturers millions. In 1967, one such manufacturer, Keuffel \& Esser Co., commissioned a study on what life would be like in a hundred years. The study predicted 3-D television and domed cities, but it didn't predict that within five years the electronic calculator would be the slide rule's death. Beware, the slide rule story says - if you don't foresee technological changes, you're in trouble.

The third is the story of videophones. Of course, there aren't any mass-market videophones, and that is the story. Thirty years ago, people were predicting them, and for thirty years they've been nowhere to be seen. Futurists also predicted "bedmaking machines, home dry-cleaning, showers that clean people with sound waves, robots that cut lawns and fight wars, steam and electric-driven cars, foamfilled tires, plastic teeth and tooth-decay vaccine." We're still waiting.

Finally, the fourth story - one that's less exciting and therefore less often told - is the story of the ATM. ATMs have made banking more convenient and saved people countless hours of standing in bank lines - a really useful invention, but nothing earth-shattering. Technology solved a problem, made our lives easier, maybe changed the economics of an industry or two, but that was that.

This perspective was, perhaps, valid in 1995 but then a few more years passed and more people connected to the Internet and the processing power of computers continued to increase. Today, we do have videophones, although not the kind imagined by telephone companies a few decades ago. Today, we still have ATMs that remain conveniences. But the story of ATMs is, I would argue, not only a story of convenience but a chapter in the story of the impact of money in electronic form. Thus, the larger story is one of how banks in particular and the financial services sector of the economy in general have been transformed in the last ten years.

New communications technologies create conveniences but new media that simply change patterns of communications may not be a strong enough force to be more deeply transformative. Information processing in new ways when added to new patterns of communication creates a much more powerful force. Printing did not simply cause a communications revolution but an information processing revolution. It was not simply a new method of distributing information but a catalyst for working with information in new ways, for creating information in new ways, and giving the printed page an authority that manuscripts did not have. It was a particularly influential force on law, where precedent acquired new authority and reliance on precedent became a foundation of legal reasoning. ${ }^{24}$

\section{II) Rule formation and the communication and processing of information}

The ICANN domain name dispute resolution process is, arguably, ODR in its most primitive form. When the UDRP process first began, one provider did have an all online process but it no longer handles cases and the two largest current providers still rely greatly on faxes and express

\footnotetext{
24 The impact of printing on law is a basic theme of Ethan Katsh, The Electronic Media and the Transformation of Law (New York: Oxford University Press, 1989). See also Elizabeth Eisenstein, The Printing Press as an Agent of Change (New York: Cambridge University Press, 1979).
}

Ethan KATSH, "Online Dispute Resolution: Some Implications for the Emergence of Law in Cyberspace", Lex 
delivery services. In other words, there is decision making at a distance but very limited online communication or software-based information processing at all.

ICANN is, for a variety of reasons, probably more of an example of how not to design an ODR process than of how to design one. There is, however, one element in the UDRP process that is noteworthy and that illustrates the role of information and communication in the emergence of rules. The one act ICANN took, probably with the intent of providing the process with a measure of legitimacy, was to require the decisions of panelists to be posted on the Web. As decisions were made, they were posted on the Web sites of the individual providers and ICANN maintained several tables on its Web site that linked to these decisions. Panelists in UDRP disputes are not bound to follow prior decisions and ICANN made no claim that the goal was to create a common law of UDRP cases. Nevertheless, the act of requiring publication in a networked environment did cause questions about consistency to be raised and does provide some lessons about opportunities for rules to emerge online that are not present offline.

Publication alone and particularly as the number of cases increased, did not provide practitioners with any systematic capability for finding similar cases. Publishing decisions did allow research to be conducted on decisions and trends and one issue of interest was whether cases with similar facts led to the same findings. The earliest research on UDRP decisions documented inconsistencies among the different providers and the magnitude of inconsistencies between providers led to one provider going out of business.

The transparency promoted by the publishing of decisions provided considerable evidence of a flawed process but never resulted in ICANN modifying the process in any way. Search engines and other informational tools could have promoted more consistent interpretation of UDRP provisions $^{25}$ but even without any direction from ICANN, pressure for consistent interpretation seems to have been growing. Recently, WIPO has placed online a summary of panelist interpretations of different sections and clauses. ${ }^{26}$ The summary documents quite strikingly how frequently panelists reached opposite conclusions in similar cases. Again, prior decisions were not meant to be binding in any way on future decisions but the release of information online gives the information a certain force of its own.

Information accessibility alone has provided slight pressure in the ICANN situation toward the emergence of uniform rules. But what might occur if an institution more interested than ICANN is in building legitimacy made its process transaparent? Institutions online that perform public functions such as dispute resolution will often use transparency to build trust and to try to secure a competitive advantage over other institutions providing similar services. Such dispute resolution entities will not be alternatives to court proceedings but the more public they are the more of an infrastructure will be provided that will allow accepted standards of behavior and practice to emerge.

It is too early to predict what kinds of novel dispute resolution institutions will emerge in cyberspace but it is not too early to be confident that the need and demand for such institutions will continue to grow. It may be true, as one critic has written, that "[T]he possibilities for private legal ordering are not limitless, ${ }^{27}$ but it is quite possible that information processing capabilities will expand the various models of private ordering. In the absence of state authority,

25 See, for example, the search engine at http://udrp.lii.info

$26 \quad$ http://arbiter.wipo.int/domains/search/overview/index.html?lang=eng

$27 \quad$ Jack L. Goldsmith, “Against Cyberanarchy,” 65 U. Chi. L. Rev. 1199, 1209 (1998).

Ethan KATSH, “Online Dispute Resolution: Some Implications for the Emergence of Law in Cyberspace”, Lex 
some creativity can be expected in generating mechanisms of enforcement. Under such a scenario, rule making may emerge tentatively, gradually and over time, rather than with a single act of recognition. Rules may emerge from shared spaces rather than sovereign spaces and from a concept of distributed authority rather than a model of a supreme authority.

Harold Berman has written that that a legal system requires that there be a "belief in the power of certain words, put certain ways, to bring about certain effects denominated as legal. This kind of magic is necessary if law is to work. ${ }^{28}$ The word magic is appropriate in the sense that we may accept the authority of rule making processes without understanding all the sources of this authority or the exact manner in which the result occurs. The details of the magic act, however, are exactly the elements in the operation of law that can be affected, perhaps superficially at the beginning but maybe at a very deep level when the information processing and communication that is part of the magic changes. When this is recognized, it will be understood that what is occurring involves an impact that goes beyond issues of jurisdiction.

ICANN decided that transparency was more important than confidentiality and if this happens more frequently, the line between private and public ordering may become less clear. Making sense of the ICANN rulings as they appeared required large investments of labor. Historians will look at ICANN as an institution that did not understand that public decision making affects perception of the legitimacy of the whole enterprise. Yet, one might envision a somewhat different set of circumstances, one in which not only are the decisions public and easily accessible but respected. We have limited experience with online versions of such processes but one of the opportunities presented by a software driven process is that it can be modified simply by changing the configuration of the software. ${ }^{29}$

\section{Conclusion}

This is an era in which change is not only occurring rapidly but at an accelerated pace. ${ }^{30}$ Change, particularly change which brings higher and higher levels of online activity, is likely to accelerate the need for mechanisms to resolve disputes. Yet, courts, are an unlikely forum for this to occur. Not only are numbers of trials far fewer than they were a few decades ago ${ }^{31}$ but judges are realizing that, as one court stated, "[T]he history of the Internet is a chronicle of innovation by improvisation, from its genesis as a national defense research network, to a medium of academic exchange, to a hacker cyber-subculture, to the commercial engine for the so-called "New Economy." Like Heraclitus at the river, we address the Internet aware that courts are ill-suited to fix its flow.",32

28 Berman, Harold, "The Background of the Western Legal Tradition in the Folklaw of the Peoples of Europe," 45 U. Chi. L. Rev. 553, 563 (1978).

$29 \quad$ Understanding how processes can be modeled in a computer language and then changed by reconfiguring the program is one of the goals of a current research project being undertaken by the National Mediaiton Board and the University of Massachusetts Center for Information Technology and Dispute Resolution and the Department of Computer Science. See National Science Foundation award \# 0429297 "Process Technology for Achieving Government Online Dispute Resolution." <http://www.fastlane.nsf.gov/servlet/showaward?award=0429297>

30 Ray Kurzweil, "The Law of Accelerating Returns" $<$ http://www.kurzweilai.net/articles/art0134.html?printable=1>

$31 \quad$ Marc Galanter, The Vanishing Trial: An Examination of Trials and Related Matters in Federal and State Courts, 1 J. Empirical Legal Stud. 459, 461 (2004).

$32 \quad$ AT\&T Corporation v. City of Portland 216 F.3d 871, 875 (2000)

Ethan KATSH, "Online Dispute Resolution: Some Implications for the Emergence of Law in Cyberspace”, Lex 
In spite of this, the fiction that courts are the "primary" form of dispute resolution still seems embedded in our culture. Similarly, court decisions are often labeled as landmark cases without considering whether, because of a changing technological landscape, any particular case will have the same kind of long term applicability that cases had in the past. Paul Schiff Berman reminds us that "[L]egal scholars and policymakers have an unfortunate tendency to assume that legal norms, once established, simply take effect and constitute a legal regime." 33 We certainly have a need for standards and for safety but we need new tools to achieve such purposes. Online dispute resolution, as it develops, may prove to be one of the more important of these tools.

33 Paul Schiff Berman, " From International Law to Law and Globalization,” 43 Colum. J. Transnat'1 L. 485, 498 (2005).

Ethan KATSH, "Online Dispute Resolution: Some Implications for the Emergence of Law in Cyberspace”, Lex 